\title{
DINÁMICA DE UN REACTOR DE BIOPELÍCULA ANAEROBIA TIPO INTERCAMBIADOR DE CALOR (RBAIC)
}

\section{Carlos Ramiro Escalera Vásquez}

\section{RESUMEN}

Las características dinámicas de un reactor de biopelícula anaerobio tipo intercambiador de calor (RBAIC), usado para el tratamiento de aguas residuales de melazas, fueron estudiadas experimentalmente. Se realizaron experimentos para estudiar la respuesta del reactor a las sobrecargas orgánicas. También se estudiaron los efectos de los cambios de temperatura de las paredes calientes y las temperaturas ambientales, sobre la eficiencia del reactor, bajo condiciones de estado estacionario. Se demostró que el RBAIC es estable ante la ocurrencia de sobrecarga orgánica. Se concluyó que existe una separación de fases microbianas dentro del reactor, en condiciones normales de operación. Es decir, las bacterias acidogénicas predominan en la masa líquida recirculante y las heteroacetogénicas y metanogénicas lo hacen en la biopelícula adherida a las paredes calientes de transferencia de calor, lo cual implica que los cambios de la temperatura de la pared afectan de mayor manera a la eficiencia de remoción, que los cambios de temperatura del entorno. El RBAIC es una configuración novedosa, con características energéticas favorables para el tratamiento de aguas residuales de la industria alimenticia.

Palabras Clave: Reactor de Biopelícula Anaerobia, Intercambio de Calor, Agua Residual de Melazas, Dinámica de Reactores. 